\title{
REPORT ON THE 1928 INTERNATIONAL CONGRESS OF MATHEMATICIANS*
}

\author{
BY L. TONELLI
}

At the Toronto Congress of 1924, Professor Salvatore Pincherle was elected president of the International Mathematical Society and the city of Bologna was chosen as the seat of the 1928 congress. A program committee was selected, the presidency being entrusted to Senator G. Albini, Rector of the University of Bologna. An executive sub-committee was also formed with Professor S. Pincherle as president, the other members being: Professor E. Bompiani, Professor P. Burgatti, Professor F. Guarducci, Professor G. Horn d'Arturo, Professor Q. Majorana, Professor U. Puppini, Professor L. Tonelli, Professor D. Zucchini, Comm. G. Borsari (treasurer) and Professor Ett. Bortolotti (general secretary). The congress was held under the distinguished patronage of $\mathrm{H}$. M. the King of Italy, and the honorary presidency of His Excellency, Benito Mussolini, the leader of the government.

The program committee, following the wishes of the majority of the Toronto delegates, invited to the congress all mathematicians, and representatives of the leading universities and academies of the world. The proceedings of the congress were divided into seven sections, and several chairmen were named for each section, their task being the detailed organization of their particular section. The arrangement of sections was as follows:

Section I. Arithmetic, Algebra, Analysis (Chairmen: M. Cipolla, G. Fubini, G. Scorza, L. Tonelli).

Section II. Geometry (Chairmen: L. Berzolari, E. Bompiani, G. Fubini, F. Severi).

Section III. Mechanics, Astronomy, Geodesy, Geophysics,

* Translated by Dr. A. O. Hickson, Brown University. 
Mathematical Physics, Theoretical Physics (Chairmen: G. Armellini, P. Burgatti, E. Fermi, T. Levi-Civita, C. Somigliana).

Section IV. Statistics, Mathematical Theory of Economics, Calculus of Probability, Actuarial Science (Chairmen: L. Amoroso, P. Cantelli, C. Gini, G. Toja).

Sectron V. Engineering and Industrial Applications (Chairmen: G. Albenga, C. Di Pirro, G. Giorgi, F. Lori, M. Panetti, C. Porro, U. Puppini, L. Silla, G. Vacchelli, G. C. Vallauri).

Secrion VI. Elementary Mathematics, Didactics, Mathematical Logic (Chairmen: U. Amaldi, G. Peano, A. Perna).

Section VII. Philosophy, History of Mathematics (Chairmen: E. Bortolotti, F. Enriques, R. Marcolongo, G. Vacca).

Eight hundred active members (those mathematicians who took part in the proceedings of the congress), 287 associate members (those belonging to the families of the delegates), and most of the members of the program committee attended the congress. Thirty-four nations were represented, and the larger delegations, except that of Italy (249 members), were: Germany with 76, Great Britain and Dominions with 64 , France with 51 , the United States with 43 , Switzerland with 33, Poland with 32, Russia and Ukraine with 35, Hungary with 22, etc.

On Sunday evening, September 2, the Italian Mathematical Society held a reception for the delegates in the hall of the Bologna Circolo di Cultura. On Monday morning, September 3 , the inaugural meeting was held in the assembly hall of the Archizinnesio in the presence of H.R. H., the Duke of Bergamo; the speakers were: Mayor Arpinati of Bologna, Senator Albini, rector of the University, Professor Pincherle, Professor Birkhoff, representative of all the foreign mathe- 
maticians, and S. E. Belluzzo, minister of Public Instruction. The last speaker formally opened the congress.

The proceedings of the congress began on the afternoon of the same day and all meetings were held in the halls of the Royal University (Via Zamboni). At the first session a general assembly was held for the nomination of the president and vice-presidents; the following nominations were made by acclamation: Professor S. Pincherle for president of the congress, and for vice-presidents Professors de la Vallée Poussin, J. Hadamard, D. Hilbert, W. H. Young, J. C. Fields, O. Veblen, E. Terradas, W. Sierpinski, H. Bohr, N. Lusin, S. Kakeya.

The general lectures, all of which were given in the mornings, were successively as follows:

D. HILBERT-Probleme der mathematischen Logik.

J. HADAMARD-Le développement et le rôle scientifique du calcul functionnel.

U. PUPPINI-Le bonifiche in Italia.

E. BOREL-Le calcul des probabilités et les sciences exactes.

O. VEBLEN-Differential invariants and geometry.

G. Castelnuovo-La geometria algebrica e la scuola Italiana.

W. H. YounG-The mathematical method and its limitations.

V. VolTERRA - La teoria dei funzionali applicata ai fenomeni ereditari.

H. WEYL-Darstellung kontinuirlichen Gruppen.

T. vON KÁRMÁN-Mathematische Probleme der modernen Aerodynamik.

L. ToNelli-Contributo italiano alla teoria delle funzioni di variabili reali.

M. FRÉCHET-L'analyse général et les espaces abstraits.

R. MARColongo-Leonardo da Vinci nella storia della matematica e della meccanica.

N. Lusin-Sur les voies de la thêorie des ensembles.

L. Amoroso-Le equazioni differenziali della dinamica economica.

The number of sectional papers, all of which were pre- 
sented in the afternoons, reached the remarkable total of almost four hundred.

A reception by the Mayor, a reception by the National Government, an orchestral concert of historical Italian music, and a banquet by the program committee of the congress occupied the evenings.

September 7 was devoted to a tour of the cities of Ravenna and Ferrara, and Lake Ledro.

Monday morning, September 10, the last day of the congress, the delegates departed for Florence, where, in the Palazzo Vecchio, Professor Birkhoff spoke on Quelques éléments mathématiques de l'art. The final session of the congress was also held here, and it was decided, completing the discussion of the preceding day, that the congress of 1932 should be held in Switzerland.

During the seven day visit of the delegates at Bologna and the closing day of the congress at Florence, everything proceeded in perfect order, and the best of relations existed between the delegates of different nationalities. To the scientific interest, determined by the interchange of ideas, of methods and of results on the most modern tendencies of mathematics, one must add the result, politically important, of bringing the international congress of mathematicians to the universality of the pre-war period.

L. TONELli 